\title{
USE OF SOCIAL MEDIA PLATFORMS BY THE ENGINEERING FACULTIES AND STUDENTS IN PUDUCHERRY - A SURVEY
}

\author{
R. Jayakumar \\ Research Scholar, Department of Library and Information Science, \\ Bharathiar University, Coimbatore, India \\ N. Tamilselvan \\ Research Guide, Chief Librarian and Head, \\ RVS College of Engineering and Technology, \\ Coimbatore, India \\ tamilselvanmn@gmail.com
}

\begin{abstract}
The paper presents the extent of utilization of social media platforms by the engineering faculties and students in Puducherry through a survey conducted with 551 respondents from nine engineering colleges. The study revealed that 91.05 percent of the total respondents made use of Skype; only 12.34 percent of the respondents checked the analytics of social media activities daily; 7.8 of the respondents used SM platforms very frequently, and 22.87 percent frequently. Interestingly, it was found that 90.41 percent of the faculty respondents made use of SM platforms for Academic purposes while 98.12 percent of the students made use of SM platforms for Sharing photos and videos. It was also opined that the use of social media platforms has positively influenced the respondents. However, a good number of respondents have also revealed that there was negative influence on the use of social media platforms.
\end{abstract}

Key words: social media, engineering faculties, engineering students, social networking sites, social media tools, social media platforms

Cite this Article: R. Jayakumar and N. Tamilselvan, Use of Social Media Platforms by the Engineering Faculties and Students in Puducherry - A Survey. International Journal of Library \& Information Science, 7(4), 2018, pp. 21-35.

http://iaeme.com/Home/issue/IJLIS?Volume=7\&Issue=4

\section{INTRODUCTION}

The evolution of the social networking sites can be traced back to the shift of internet technology from Web 1.0 to Web 2.0. Web 2.0 is described as the interactive platform where two or more persons are getting involved virtually engaging in the activities (Kroski, 2007). 
Social networking sites became one of the most used channels of informal communication and ways to explore and exploit the knowledge resources (Steinfield et al., 2008; Haque, 2013) and they are the most sought after sharing platforms on the internet (Alexa, 2008). Social networking sites allow their customers to interact with others sophistically and express their personal feelings by sharing with friends and families (Haque, 2013; Governatoria \& Iannella, 2011; Murray \& Waller, 2007). Classroom reading and acquiring of knowledge is becoming real time through the online media which is the fashion of the time (Russo, et al., 2009). Importantly these platforms provide a lot more than an opportunity for collaboration irrespective of the space and time (Minocha, 2009). Thus, social networking is the process where a relationship is created by a group of people with same interest. Social networking sites could be of two types namely Internal Social Networking Sites and External Social Networking Sites (Suraweere, 2010).

It is clear from the literature that social networking sites are popular and widely used by the academic fraternity in India. Though there are large number of academic oriented social networking sites available to use for academic and research purpose, only limited number of social networking sites or tools are being used in the country because of lack of awareness and experience. Imparting proper education and orientation to use social networking sites for academic purpose would result in high scholarly output because of easy access to primary data and swift and instant responses from the target audiences. Therefore, the present study intends to assess the extent of utilization of social media platforms by the faculties and students of selected engineering colleges in Puducherry.

\section{LITERATURE REVIEW}

There are number of studies which appeared from 2000 to till date on social networking sites. A few prominent studies reported very recently related to the current study have been reviewed and presented below:

Asmi and Margam (2018) reported that research scholars were aware of social networking sites. Academic social networking sites such as ResearchGate and Academia.edu were found to be the most used ones by the respondents. The constraints identified while using social media were time-consuming and data security. Yan and Zhang (2018) suggested that social media tools can serve as indicators for evaluating the research activities of research institutions, and such sites can be helpful and credible for acquiring resources, keeping informed about research, and promoting academic influence. Zientek et al., (2018) emphasized that the use of Google Scholar supplements the researchers in reporting their research, improving future research, scholarly networking for collaborations, and marketing their research.

Aleryani, Mofleh and Alariki (2017) found that more than 33\% of researchers are not aware of academic social network sites. Ali and Richardson (2017) showed that accruing citations was the main reason for the respondents to upload their publications. The studies by Bardakc1, Arslan and U"never (2017), Meishar-Tal and Pieterse (2017), and Mering (2017) proved that the use of social network sites enhanced the research collaboration and information development with researchers across the globe. Jeng et al., (2017) motivated the respondents by stimulating scholarly interactions to reduce the rate of confusion, improving the clarity of questions, and promoting scholarly content management. The use of the social networking sites creates impact on the research work among the respondents. (Kenchakkanavar, Hadagali \& Ranadev, 2017; Manca \& Ranieri, 2017) 


\section{OBJECTIVES OF THE STUDY}

The study was conducted based on the following objectives:

- To identify the extent of use of social media platforms by the faculties and students of engineering colleges in Puducherry based on their demographic profile;

- To assess how frequently the respondents make use of social media platforms for checking the analytics of social media activities;

- To examine the purpose of using social media platforms;

- To seek the opinion of the respondents on the Length of using SM platforms, Time spent, Places of using SM platforms, and Devices used for accessing SM platforms; and

- To identify how the respondents have been influenced positively and negatively by using social media platforms.

\section{MATERIALS AND METHODS}

A questionnaire was used to get the data related to demographic profile of the respondents and the awareness on social networking sites meant for academic related activities. A total of 716 faculty members and 9536 students were spread over the selected nine engineering colleges in Puducherry. The Proportionate Stratified Random Sampling Technique was adopted. 10 percent of Faculties and 5 percent of students were proportionately taken from each college for the study. Table 1 depicts the collection of duly filled in questionnaires.

Table 1 Status of the Respondents

\begin{tabular}{|c|c|c|c|c|c|c|}
\hline $\begin{array}{l}\dot{z} \\
\dot{i}\end{array}$ & 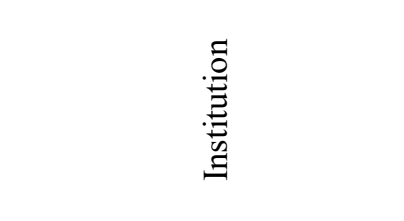 & 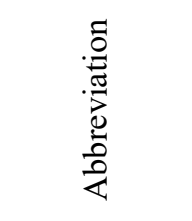 & 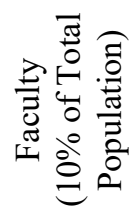 & 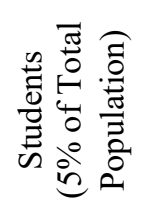 & 䅇 & 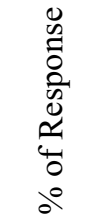 \\
\hline 1 & $\begin{array}{l}\text { Pondicherry Engineering } \\
\text { College }\end{array}$ & PEC & 14 & 123 & 137 & 24.86 \\
\hline 2 & $\begin{array}{l}\text { Achariya College of } \\
\text { Engineering \& Technology }\end{array}$ & ACET & 9 & 50 & 59 & 10.71 \\
\hline 3 & $\begin{array}{l}\text { Alpha College of } \\
\text { Engineering \& Technology }\end{array}$ & ALCET & 4 & 33 & 37 & 6.72 \\
\hline 4 & $\begin{array}{l}\text { Christ College of } \\
\text { Engineering \& Technology }\end{array}$ & CCET & 9 & 65 & 74 & 13.43 \\
\hline 5 & $\begin{array}{l}\text { Dr. SJS Paul Memorial } \\
\text { College of Engineering \& } \\
\text { Technology }\end{array}$ & PMCET & 6 & 30 & 36 & 6.53 \\
\hline 6 & $\begin{array}{l}\text { Manakula Vinayagar } \\
\text { Institute of Technology }\end{array}$ & MVIT & 10 & 75 & 85 & 15.43 \\
\hline 7 & $\begin{array}{l}\text { RAAK College of } \\
\text { Engineering \& Technology }\end{array}$ & RAAKCET & 3 & 8 & 11 & 2.00 \\
\hline 8 & $\begin{array}{l}\text { Rajiv Gandhi College of } \\
\text { Engineering \& Technology }\end{array}$ & RGCET & 15 & 75 & 90 & 16.33 \\
\hline 9 & $\begin{array}{l}\text { Sri Ganesh College of } \\
\text { Engineering \& Technology }\end{array}$ & SGCET & 3 & 19 & 22 & 3.99 \\
\hline \multicolumn{3}{|c|}{ Total } & 73 & 478 & 551 & 100 \\
\hline
\end{tabular}




\section{RESULTS AND DISCUSSION}

The collected data from 551 respondents which constitute faculties and students of nine engineering colleges in Puducherry were duly analysed and the results are presented below:

\section{Use of Social Media platforms by the category of respondents}

Table 2 reports the category wise use of Social Media platforms for various purposes. The result indicates that out of 73 faculties, 90.74 percent of them made use of WhatsApp followed by Linkedin (88.89\%), Twitter (88.46\%), Skype $(87.50 \%)$, Youtube $(86.44 \%)$, Google Talk (84.48\%), Facebook (81.82\%), Google + (80\%), Instagram (78\%), Pinterest (77.08\%), Foursquare (75.56\%), Tumblr (73.68\%), Reddit $(71.88 \%)$, MySpace $(71.74 \%)$, Meetme (70.45\%), Ibibo (70.21\%), Flickr (65.79\%), Picasa (65.71\%), Meetup (63.64\%), Tagged (61.11\%), Yahoo!Buzz (60.53\%), Xing (59.46\%), Metacafe (54.76\%), Hike (53.33\%), Yahoo!Pulse (52.94\%), Vine (50\%), Bebo (44.44\%), Dailymotion (44\%), Hangout (40\%), Yammer (37.14\%), Snapchat (36.67\%), Shtyle (33.33\%), Zedge (33.33\%), Ask.fm (32.35\%), Ning (32.14\%), Plaxor (22.22\%), Zorpia (17.91\%), and Zoomr (17.74\%).

On the other hand, out of 478 students, 95.34 percent of them made use of Google Talk followed by Ask.fm (94.83\%), Skype (94.59\%), Youtube (94.19\%), Instagram (94.01\%), Tagged (93.68\%), Ibibo (93.53\%), Dailymotion (93.51\%), Hangout (93.21\%), Twitter (93.18\%), Flickr (93.1\%), Meetup (92.91\%), MySpace (92.9\%), Hike (92.87\%), Bebo (92.58\%), Zedge (92.28\%), Google + (91.69\%), Foursquare $(91.57 \%)$, Picasa $(90.73 \%)$, Ning (90.19\%), Metacafe (90.17\%), Xing (89.82\%), Meetme (89.8\%), Facebook (89.64\%), Zoomr (89.47\%), Vine (89.31\%), Snapchat (88.99\%), Tumblr $(88.92 \%)$, WhatsApp $(88.51 \%)$, Reddit (88.35\%), Pinterest (86.86\%), Shtyle (86.77\%), Linkedin (85.57\%), Plaxor $(85.02 \%)$, Yahoo!Pulse (81.03\%), Yahoo!Buzz (78.8\%), Yammer (77.78\%), and Zorpia (76.9\%).

Overall, it was observed that out of 551 total respondents, 91.05 percent of the respondents made use of Skype followed by Twitter (90.82\%), Youtube (90.32\%), Google Talk (89.91\%), WhatsApp (89.63\%), Linkedin (87.23\%), Instagram (86\%), Google + (85.84\%), Facebook (85.73\%), Foursquare (83.56\%), MySpace $(82.32 \%)$, Pinterest $(81.97 \%)$, Ibibo (81.87\%), Tumblr (81.3\%), Meetme (80.13\%), Reddit $(80.11 \%)$, Flickr $(79.45 \%)$, Meetup (78.27\%), Picasa (78.22\%), Tagged (77.4\%), Xing (74.64\%), Hike $(73.10 \%)$, Metacafe (72.47\%), Vine (69.66\%), Yahoo!Buzz (69.66\%), Dailymotion (68.76\%), Bebo (68.51\%), Yahoo!Pulse (66.99\%), Hangout (66.6\%), Ask.fm (63.59\%), Snapchat (62.83\%), Zedge (62.81\%), Ning (61.17\%), Shtyle (60.05\%), Yammer $(57.46 \%)$, Plaxor $(53.62 \%)$, Zoomr (53.61\%), and Zorpia (47.4\%).

\section{Frequency of checking the analytics of social media activities by the respondents}

Table 3 gives the frequency of checking the analytics of social media activities. The institution wise analysis reveals that out of 68 respondents who checked the analytics of social media activities daily, 18(26.47\%) respondents were from PEC which ranks first in order followed by RGCET (23.53\%), MVIT (16.18\%), CCET (11.76\%), ACET (8.82\%), ALCET (4.41\%), PMCET (2.94\%), RAAKCET (2.94\%), and SGCET (2.94\%). 
Table 2 Category wise use of Social Media platforms

\begin{tabular}{|c|c|c|c|c|c|c|c|c|c|c|c|c|}
\hline \multirow{2}{*}{ Social Media platforms } & \multicolumn{4}{|c|}{ Faculty } & \multicolumn{4}{|c|}{ Students } & \multicolumn{4}{|c|}{ Total } \\
\hline & Use & $\%$ & Non-Use & $\%$ & Use & $\%$ & Non-Use & $\%$ & Use & $\%$ & Non-Use & $\%$ \\
\hline Ask.fm & 11 & 32.35 & 23 & 67.65 & 385 & 94.83 & 21 & 5.17 & 396 & 63.59 & 44 & 36.41 \\
\hline Bebo & 12 & 44.44 & 15 & 55.56 & 362 & 92.58 & 29 & 7.42 & 374 & 68.51 & 44 & 31.49 \\
\hline Dailymotion & 11 & 44.00 & 14 & 56.00 & 346 & 93.51 & 24 & 6.49 & 357 & 68.76 & 38 & 31.24 \\
\hline Facebook & 36 & 81.82 & 8 & 18.18 & 372 & 89.64 & 43 & 10.36 & 408 & 85.73 & 51 & 14.27 \\
\hline Flickr & 25 & 65.79 & 13 & 34.21 & 351 & 93.10 & 26 & 6.90 & 376 & 79.45 & 39 & 20.55 \\
\hline Foursquare & 34 & 75.56 & 11 & 24.44 & 413 & 91.57 & 38 & 8.43 & 447 & 83.56 & 49 & 16.44 \\
\hline Google + & 32 & 80.00 & 8 & 20.00 & 364 & 91.69 & 33 & 8.31 & 396 & 85.84 & 41 & 14.16 \\
\hline Google Talk & 49 & 84.48 & 9 & 15.52 & 389 & 95.34 & 19 & 4.66 & 438 & 89.91 & 28 & 10.09 \\
\hline Hangout & 12 & 40.00 & 18 & 60.00 & 398 & 93.21 & 29 & 6.79 & 410 & 66.60 & 47 & 33.40 \\
\hline Hike & 24 & 53.33 & 21 & 46.67 & 391 & 92.87 & 30 & 7.13 & 415 & 73.10 & 51 & 26.90 \\
\hline Ibibo & 33 & 70.21 & 14 & 29.79 & 376 & 93.53 & 26 & 6.47 & 409 & 81.87 & 40 & 18.13 \\
\hline Instagram & 39 & 78.00 & 11 & 22.00 & 345 & 94.01 & 22 & 5.99 & 384 & 86.00 & 33 & 14.00 \\
\hline Linkedin & 48 & 88.89 & 6 & 11.11 & 332 & 85.57 & 56 & 14.43 & 380 & 87.23 & 62 & 12.77 \\
\hline Meetme & 31 & 70.45 & 13 & 29.55 & 361 & 89.80 & 41 & 10.20 & 392 & 80.13 & 54 & 19.87 \\
\hline Meetup & 21 & 63.64 & 12 & 36.36 & 380 & 92.91 & 29 & 7.09 & 401 & 78.27 & 41 & 21.73 \\
\hline Metacafe & 23 & 54.76 & 19 & 45.24 & 367 & 90.17 & 40 & 9.83 & 390 & 72.47 & 59 & 27.53 \\
\hline MySpace & 33 & 71.74 & 13 & 28.26 & 301 & 92.90 & 23 & 7.10 & 334 & 82.32 & 36 & 17.68 \\
\hline Ning & 9 & 32.14 & 19 & 67.86 & 331 & 90.19 & 36 & 9.81 & 340 & 61.17 & 55 & 38.83 \\
\hline Picasa & 23 & 65.71 & 12 & 34.29 & 362 & 90.73 & 37 & 9.27 & 385 & 78.22 & 49 & 21.78 \\
\hline Pinterest & 37 & 77.08 & 11 & 22.92 & 337 & 86.86 & 51 & 13.14 & 374 & 81.97 & 62 & 18.03 \\
\hline Plaxor & 8 & 22.22 & 28 & 77.78 & 352 & 85.02 & 62 & 14.98 & 360 & 53.62 & 90 & 46.38 \\
\hline Reddit & 23 & 71.88 & 9 & 28.13 & 311 & 88.35 & 41 & 11.65 & 334 & 80.11 & 50 & 19.89 \\
\hline Shtyle & 9 & 33.33 & 18 & 66.67 & 282 & 86.77 & 43 & 13.23 & 291 & 60.05 & 61 & 39.95 \\
\hline Skype & 49 & 87.50 & 7 & 12.50 & 385 & 94.59 & 22 & 5.41 & 434 & 91.05 & 29 & 8.95 \\
\hline Snapchat & 11 & 36.67 & 19 & 63.33 & 291 & 88.99 & 36 & 11.01 & 302 & 62.83 & 55 & 37.17 \\
\hline Tagged & 22 & 61.11 & 14 & 38.89 & 267 & 93.68 & 18 & 6.32 & 289 & 77.40 & 32 & 22.60 \\
\hline Tumblr & 28 & 73.68 & 10 & 26.32 & 289 & 88.92 & 36 & 11.08 & 317 & 81.30 & 46 & 18.70 \\
\hline Twitter & 46 & 88.46 & 6 & 11.54 & 369 & 93.18 & 27 & 6.82 & 415 & 90.82 & 33 & 9.18 \\
\hline Vine & 21 & 50.00 & 21 & 50.00 & 234 & 89.31 & 28 & 10.69 & 255 & 69.66 & 49 & 30.34 \\
\hline WhatsApp & 49 & 90.74 & 5 & 9.26 & 416 & 88.51 & 54 & 11.49 & 465 & 89.63 & 59 & 10.37 \\
\hline Xing & 22 & 59.46 & 15 & 40.54 & 256 & 89.82 & 29 & 10.18 & 278 & 74.64 & 44 & 25.36 \\
\hline Yahoo!Buzz & 23 & 60.53 & 15 & 39.47 & 249 & 78.80 & 67 & 21.20 & 272 & 69.66 & 82 & 30.34 \\
\hline Yahoo!Pulse & 18 & 52.94 & 16 & 47.06 & 235 & 81.03 & 55 & 18.97 & 253 & 66.99 & 71 & 33.01 \\
\hline Yammer & 13 & 37.14 & 22 & 62.86 & 189 & 77.78 & 54 & 22.22 & 202 & 57.46 & 76 & 42.54 \\
\hline Youtube & 51 & 86.44 & 8 & 13.56 & 438 & 94.19 & 27 & 5.81 & 489 & 90.32 & 35 & 9.68 \\
\hline Zedge & 23 & 33.33 & 46 & 66.67 & 311 & 92.28 & 26 & 7.72 & 334 & 62.81 & 72 & 37.19 \\
\hline Zoomr & 11 & 17.74 & 51 & 82.26 & 323 & 89.47 & 38 & 10.53 & 334 & 53.61 & 89 & 46.39 \\
\hline Zorpia & 12 & 17.91 & 55 & 82.09 & 213 & 76.90 & 64 & 23.10 & 225 & 47.40 & 119 & 52.60 \\
\hline
\end{tabular}

Out of 143 respondents who checked the analytics of social media activities few times a week, 28(19.58\%) respondents each were from PEC and RGCET respectively followed by MVIT (16.08\%), CCET (14.69\%), ACET (10.49\%), ALCET (8.39\%), PMCET (6.29\%), SGCET $(3.50 \%)$, and RAAKCET (1.40\%). Out of 210(38.11\%) respondents who checked the analytics of social media activities once a week, 50(23.81\%) respondents were from PEC followed by PEC (23.81\%), MVIT (17.62\%), CCET (15.24\%), RGCET (14.76\%), ACET (10\%), PMCET (6.67\%), ALCET (5.24\%), SGCET (5.24\%), and RAAKCET (1.43\%).

On the other hand, out of $87(15.79 \%)$ respondents who checked the analytics of social media activities rarely, 28(32.18\%) respondents were from PEC followed by ACET (13.79\%), RGCET (13.79\%), CCET (10.34\%), MVIT (10.34\%), ALCET (8.05\%), PMCET (6.90\%), RAAKCET $(2.30 \%)$, and SGCET $(2.30 \%)$. Out of $43(7.8 \%)$ respondents who never checked the analytics of social media activities, 13(30.23\%) respondents were from PEC followed by ACET (11.63\%), PMCET (11.63\%), MVIT (11.63\%), ALCET (9.30\%), CCET (9.30\%), RGCET (6.98\%), RAAKCET (4.65\%), and SGCET (4.65\%).

The overall result indicates that out of 551 respondents from nine engineering colleges in Puducherry, 68(12.34\%) respondents checked the analytics of social media activities daily; $143(25.95 \%)$ respondents checked the analytics of social media activities few times a week; 
$210(38.11 \%)$ respondents checked the analytics of social media activities once a week; $87(15.79 \%)$ respondents checked the analytics of social media activities rarely; and $43(7.8 \%)$ respondents never checked the analytics of social media activities.

\section{Frequency of using Social Media platforms by Institution}

Table 4 details the institution wise frequency of using Social Media platforms. The institution wise analysis reveals that out of 43 respondents who used Social media platforms Very Frequently, 14(32.56\%) respondents were from PEC which ranks first in order followed by RGCET (20.93\%), MVIT (13.95\%), CCET (9.30\%), ACET (6.98\%), ALCET (6.98\%), PMCET $(6.98 \%)$, and RAAKCET $(2.33 \%)$. It is quite surprising that no respondent from SGCET used very frequently. Out of 126 respondents who used Social media platform Frequently, 32(25.4\%) respondents were from PEC which ranks first in order followed by RGCET (18.25\%), CCET (15.08\%), MVIT (14.29\%), ACET (9.52\%), ALCET (6.35\%), PMCET (5.56\%), SGCET (3.97\%), and RAAKCET (1.59\%). Out of 223 respondents who used Social media platforms sometimes, 49(21.97\%) respondents were from PEC which ranks first in order followed byACET (16.14\%), MVIT (16.14\%), RGCET (14.8\%), CCET (13.9\%), ALCET (6.73\%), PMCET (4.48\%), SGCET (3.59\%), and RAAKCET (2.24\%).

On the other hand, out of $84(15.25 \%)$ respondents who used Social media platforms rarely, 18(21.43\%) respondents were from PEC followed by MVIT (20.24\%), RGCET (19.05\%), PMCET (9.52\%), CCET (8.33\%), ACET (7.14\%), ALCET (5.95\%), SGCET $(5.95 \%)$, and RAAKCET $(2.38 \%)$. Out of $75(13.61 \%)$ respondents who never used Social media platforms, 24(32\%) respondents were from PEC followed by CCET (17.33\%), RGCET (12\%), PMCET (10.67\%), MVIT (10.67\%), ALCET (8\%), SGCET (5.33\%), ACET (2.67\%), and RAAKCET (1.33\%).

Table 3 Frequency of checking the analytics of social media activities

\begin{tabular}{|c|c|c|c|c|c|c|c|c|c|c|c|c|}
\hline Institution & Daily & $\%$ & Few times a week & $\%$ & Once a week & $\%$ & Rarely & $\%$ & Never & $\%$ & Total & $\%$ \\
\hline PEC & 18 & 26.47 & 28 & 19.58 & 50 & 23.81 & 28 & 32.18 & 13 & 30.23 & 137 & 24.86 \\
\hline ACET & 6 & 8.82 & 15 & 10.49 & 21 & 10.00 & 12 & 13.79 & 5 & 11.63 & 59 & 10.71 \\
\hline ALCET & 3 & 4.41 & 12 & 8.39 & 11 & 5.24 & 7 & 8.05 & 4 & 9.30 & 37 & 6.72 \\
\hline CCET & 8 & 11.76 & 21 & 14.69 & 32 & 15.24 & 9 & 10.34 & 4 & 9.30 & 74 & 13.43 \\
\hline PMCET & 2 & 2.94 & 9 & 6.29 & 14 & 6.67 & 6 & 6.90 & 5 & 11.63 & 36 & 6.53 \\
\hline MVIT & 11 & 16.18 & 23 & 16.08 & 37 & 17.62 & 9 & 10.34 & 5 & 11.63 & 85 & 15.43 \\
\hline RAAKCET & 2 & 2.94 & 2 & 1.40 & 3 & 1.43 & 2 & 2.30 & 2 & 4.65 & 11 & 2.00 \\
\hline RGCET & 16 & 23.53 & 28 & 19.58 & 31 & 14.76 & 12 & 13.79 & 3 & 6.98 & 90 & 16.33 \\
\hline SGCET & 2 & 2.94 & 5 & 3.50 & 11 & 5.24 & 2 & 2.30 & 2 & 4.65 & 22 & 3.99 \\
\hline Total & 68 & 100 & 143 & 100 & 210 & 100 & 87 & 100 & 43 & 100 & 551 & 100 \\
\hline$\%$ & 12.34 & & 25.95 & & 38.11 & & 15.79 & & 7.80 & & 100 & \\
\hline
\end{tabular}

Table 4 Institution wise Frequency of using Social Media platforms

\begin{tabular}{|c|c|c|c|c|c|c|c|c|c|c|c|c|}
\hline Institution & Very Frequently & $\%$ & Frequently & $\%$ & Sometimes & $\%$ & Rarely & $\%$ & Never & $\%$ & Total & $\%$ \\
\hline PEC & 14 & 32.56 & 32 & 25.40 & 49 & 21.97 & 18 & 21.43 & 24 & 32.00 & 137 & 24.86 \\
\hline ACET & 3 & 6.98 & 12 & 9.52 & 36 & 16.14 & 6 & 7.14 & 2 & 2.67 & 59 & 10.71 \\
\hline ALCET & 3 & 6.98 & 8 & 6.35 & 15 & 6.73 & 5 & 5.95 & 6 & 8.00 & 37 & 6.72 \\
\hline CCET & 4 & 9.30 & 19 & 15.08 & 31 & 13.90 & 7 & 8.33 & 13 & 17.33 & 74 & 13.43 \\
\hline PMCET & 3 & 6.98 & 7 & 5.56 & 10 & 4.48 & 8 & 9.52 & 8 & 10.67 & 36 & 6.53 \\
\hline MVIT & 6 & 13.95 & 18 & 14.29 & 36 & 16.14 & 17 & 20.24 & 8 & 10.67 & 85 & 15.43 \\
\hline RAAKCET & 1 & 2.33 & 2 & 1.59 & 5 & 2.24 & 2 & 2.38 & 1 & 1.33 & 11 & 2.00 \\
\hline RGCET & 9 & 20.93 & 23 & 18.25 & 33 & 14.80 & 16 & 19.05 & 9 & 12.00 & 90 & 16.33 \\
\hline SGCET & 0 & 0.00 & 5 & 3.97 & 8 & 3.59 & 5 & 5.95 & 4 & 5.33 & 22 & 3.99 \\
\hline Total & 43 & 100 & 126 & 100 & 223 & 100 & 84 & 100 & 75 & 100 & 551 & 100 \\
\hline$\%$ & 7.80 & & 22.87 & & 40.47 & & 15.25 & & 13.61 & & 100 & \\
\hline
\end{tabular}

The overall result indicates that out of 551 respondents from nine engineering colleges in Puducherry, 43(7.8\%) respondents used Social Media platforms very frequently; $126(22.87 \%)$ 
respondents used Social Media platforms frequently; 223(40.47\%) respondents used Social Media platforms sometimes; 84(15.25\%) respondents used Social Media platforms rarely; and $75(13.61 \%)$ respondents never used Social Media platforms.

\section{Opinion of the respondents on the Length of using SM platforms}

Figure 1 indicates the institution wise length of using SM platforms. The institution wise analysis reveals that out of 25 respondents who used social media platforms Less than a Month, 5(20\%) respondents each were from MVIT and RGCET followed by PEC (12\%), ACET (8\%), ALCET (8\%), CCET (8\%), PMCET (8\%), RAAKCET (8\%), and SGCET (8\%).

With regard to the length of using social media platforms for 1-6 months, out of 66 respondents, $16(24.24 \%)$ are from PEC followed by CCET (16.67\%), ACET (12.12\%), RGCET (12.12\%), MVIT (10.61\%), ALCET (7.58\%), PMCET (7.58\%), RAAKCET (4.55\%), and SGCET (4.55\%). As far as the length of using social media platforms for 6 months - 1 year are concerned, out of 110 respondents, $23(20.91 \%)$ are from PEC followed by CCET (20\%), ACET (19.09\%), MVIT (14.55\%), ALCET (8.18\%), RGCET $(8.18 \%)$, PMCET (4.55\%), SGCET (2.73\%), and RAAKCET (1.82\%).

In the case of using social media platforms for 1-2 years, out of 187 respondents, 49 (26.2\%) are from PEC followed by RGCET (20.86\%), MVIT (15.51\%), CCET (11.76\%), ACET (9.63\%), ALCET (5.35\%), SGCET (5.35\%), PMCET (4.28\%), and RAAKCET $(1.07 \%)$. With regard to the length of using social media platforms for more than 2 years, out of 163 respondents, $46(28.22 \%)$ are from PEC followed by RGCET (17.79\%), MVIT $(17.18 \%)$, CCET (10.43\%), PMCET (9.82\%), ALCET (6.75\%), ACET (6.13\%), SGCET $(2.45 \%)$, and RAAKCET $(1.23 \%)$.

The overall result indicates that out of 551 respondents from nine engineering colleges in Puducherry, 25 (4.54\%) respondents used SM platforms for Less than a Month; 66 (11.98\%) respondents used SM platforms for 1-6 months; 110 (19.96\%) respondents used SM platforms for 6 months to 1 year; 187 (33.94\%) respondents used SM platforms for 1-2 years; and 163 $(29.58 \%)$ respondents used SM platforms for more than 2 years.

\section{Opinion of the respondents on Time spent on SM platforms}

Table 5 represents the institution wise opinion of the respondents on the Time spent on SM platforms in a week. The institution wise analysis reveals that out of 101 respondents who spent time on social media platforms Less than an hour a week, $21(20.79 \%)$ respondents were from PEC followed by ACET (16.83\%), CCET (14.85\%), MVIT (10.89\%), ALCET (8.91\%), PMCET (8.91\%), RGCET (8.91\%), RAAKCET (4.95\%), and SGCET (4.95\%).

As far as the time spent on using social media platforms for 1-2 hours a week are concerned, out of 162 respondents, $42(25.93 \%)$ are from PEC followed by RGCET (20.99\%), MVIT (14.81\%), CCET (11.73\%), ACET (8.02\%), ALCET (6.79\%), PMCET $(6.17 \%)$, SGCET $(4.32 \%)$, and RAAKCET $(1.23 \%)$. With regard to the time spent on using social media platforms for 2-4 hours a week, out of 139 respondents, $36(25.9 \%)$ are from PEC followed by RGCET (16.55\%), ACET (12.95\%), MVIT (12.95\%), CCET (12.23\%), ALCET (7.91\%), PMCET (5.76\%), SGCET (4.32\%), and RAAKCET (1.44\%). 


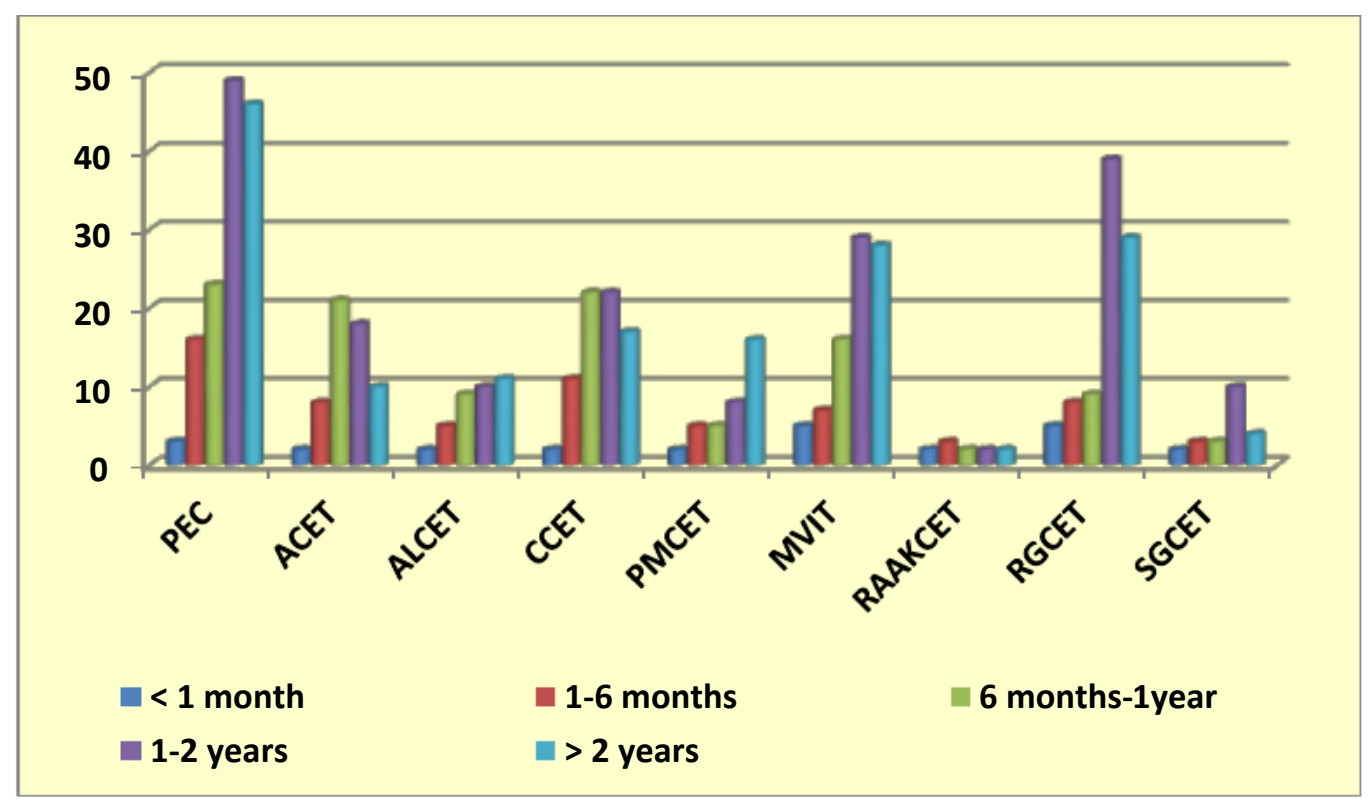

Figure 1 Opinion of the respondents on the Length of using SM platforms

In the case of time spent on using social media platforms for 5-10 hours a week, out of 114 respondents, 29 (25.44\%) are from PEC followed by MVIT (23.68\%), RGCET (16.67\%), CCET (14.04\%), ACET (6.14\%), PMCET (6.14\%), ALCET (4.39\%), RAAKCET (1.75\%), and SGCET (1.75\%).

Table 5 Opinion of the respondents on the Time spent on SM platforms in a week

\begin{tabular}{|c|c|c|c|c|c|c|c|c|c|c|c|c|}
\hline 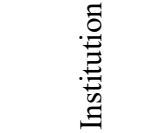 & $\begin{array}{l}\stackrel{\Xi}{\bar{g}} \\
\stackrel{\Xi}{v}\end{array}$ & $a^{\circ}$ & $\begin{array}{l}\stackrel{n}{g} \\
\stackrel{I}{I}\end{array}$ & $0^{\circ}$ & $\begin{array}{l}\stackrel{n}{\Xi} \\
\stackrel{+}{\sim} \\
\end{array}$ & $0^{\circ}$ & $\frac{n}{\frac{n}{3}}$ & $0^{\circ}$ & $\frac{\infty}{\Xi}$ & $a^{\circ}$ & 氶 & $a^{\circ}$ \\
\hline PEC & 21 & 20.79 & 42 & 25.93 & 36 & 25.90 & 29 & 25.44 & 9 & 25.71 & 137 & 24.86 \\
\hline ACET & 17 & 16.83 & 13 & 8.02 & 18 & 12.95 & 7 & 6.14 & 4 & 11.43 & 59 & 10.71 \\
\hline ALCET & 9 & 8.91 & 11 & 6.79 & 11 & 7.91 & 5 & 4.39 & 1 & 2.86 & 37 & 6.72 \\
\hline CCET & 15 & 14.85 & 19 & 11.73 & 17 & 12.23 & 16 & 14.04 & 7 & 20.00 & 74 & 13.43 \\
\hline PMCET & 9 & 8.91 & 10 & 6.17 & 8 & 5.76 & 7 & 6.14 & 2 & 5.71 & 36 & 6.53 \\
\hline MVIT & 11 & 10.89 & 24 & 14.81 & 18 & 12.95 & 27 & 23.68 & 5 & 14.29 & 85 & 15.43 \\
\hline RAAKCET & 5 & 4.95 & 2 & 1.23 & 2 & 1.44 & 2 & 1.75 & 0 & 0.00 & 11 & 2.00 \\
\hline RGCET & 9 & 8.91 & 34 & 20.99 & 23 & 16.55 & 19 & 16.67 & 5 & 14.29 & 90 & 16.33 \\
\hline SGCET & 5 & 4.95 & 7 & 4.32 & 6 & 4.32 & 2 & 1.75 & 2 & 5.71 & 22 & 3.99 \\
\hline Total & 101 & 100 & 162 & 100 & 139 & 100 & 114 & 100 & 35 & 100 & 551 & 100 \\
\hline$\%$ & 18.33 & & 29.40 & & 25.23 & & 20.69 & & 6.35 & & 100 & \\
\hline
\end{tabular}

With regard to the time spent on using social media platforms for more than 11 hours a week, out of 35 respondents, 9 (25.71\%) are from PEC followed by CCET (20\%), MVIT (14.29\%), RGCET (14.29\%), ACET (11.43\%), PMCET (5.71\%), SGCET (5.71\%), and ALCET $(2.86 \%)$ while none was found from RAAKCET.

The overall result indicates that out of 551 respondents from nine engineering colleges in Puducherry, 101 (18.33\%) respondents spent less than one hour a week on SM platforms; 162 (29.4\%) respondents spent 1-2 hours a week on SM platforms; 139 (25.23\%) respondents spent 2-4 hours a week on SM platforms; 114 (20.69\%) respondents spent 5-10 hours a week on SM platforms; and $35(6.35 \%)$ respondents spent more than 11 hours a week on SM platforms. 


\section{Opinion of the respondents on the Places of using SM platforms}

Table 6 represents the institution wise opinion of the respondents on the Places of using SM platforms. Out of 551 total respondents, $110(19.96 \%)$ of them opined that they used Library for accessing to SM platforms while 169 (30.67\%) used Hostels; 200 (36.3\%) used Institute Campus; and 72 (13.07\%) used Cyber Café.

The institution wise analysis reveals that out of 110 respondents who used Library for accessing to SM platforms, $26(23.64 \%)$ respondents were from PEC followed by MVIT (21.82\%), CCET (12.73\%), ACET (10.91\%), RGCET (10.91\%), PMCET (7.27\%), ALCET $(6.36 \%)$, SGCET $(3.64 \%)$, and RAAKCET $(2.73 \%)$. With regard to the use of Hostels for accessing to SM platforms, out of 169 respondents, 48(28.4\%) are from PEC followed by RGCET (17.16\%), MVIT (13.02\%), ACET (11.24\%), ALCET (9.47\%), CCET (8.88\%), PMCET (5.92\%), RAAKCET (2.96\%), and SGCET (2.96\%).

As far as the use of Institute Campus for accessing to SM platforms is concerned, out of 200 respondents, 49 (24.5\%) are from PEC followed by RGCET (19\%), CCET (18\%), MVIT (12\%), ACET (9.5\%), PMCET (6\%), SGCET (5.5\%), ALCET (4.5\%), and RAAKCET (1\%).

With regard to the use of Cyber Café for accessing to SM platforms, out of 72 respondents, $15(20.83 \%)$ are from MVIT followed by PEC (19.44\%), RGCET (15.28\%), ACET (12.5\%), CCET (12.5\%), PMCET (8.33\%), ALCET (6.94\%), SGCET (2.78\%), and RAAKCET (1.39\%).

\section{Opinion of the respondents on the Devices used for SM platforms}

Table 7 represents the institution wise opinion of the respondents on the Devices used for SM platforms. Out of 551 total respondents, 64 (11.62\%) of them opined that they used Personal Computers for accessing to SM platforms while 175 (31.76\%) used Laptop; 249 (45.19\%) used Mobile phones; and 63 (11.43\%) used Tablets.

The institution wise analysis reveals that out of 64 respondents who used Personal Computers for accessing to SM platforms, 12 (18.75\%) respondents were from PEC followed by CCET (14.06\%), MVIT (14.06\%), RGCET (14.06\%), ACET (12.50\%), PMCET (9.38\%), ALCET (7.81\%), SGCET (6.25\%), and RAAKCET (3.13\%). With regard to the use of Laptops for accessing to SM platforms, out of 175 respondents, $43(24.57 \%)$ are from PEC followed by RGCET (14.86\%), MVIT (14.29\%), ACET (10.86\%), CCET (10.86\%), PMCET (9.14\%), ALCET (8\%), SGCET (4\%), and RAAKCET (3.43\%). As far as the use of Mobile Phones for accessing to SM platforms is concerned, out of 249 respondents, 65 (26.1\%) are from PEC followed by MVIT (18.07\%), RGCET (17.67\%), CCET (14.86\%), ACET (9.24\%), ALCET (5.22\%), PMCET (4.42\%), SGCET (3.61\%), and RAAKCET $(0.8 \%)$.

Table 6 Opinion of the respondents on the Places of using SM platforms

\begin{tabular}{|l|c|c|c|c|c|c|c|c|c|c|}
\hline Institution & Library & $\mathbf{\%}$ & Hostel & $\mathbf{\%}$ & Institute Campus & $\mathbf{\%}$ & Cyber Café & \% & Total & \% \\
\hline PEC & 26 & 23.64 & 48 & 28.40 & 49 & 24.50 & 14 & 19.44 & 137 & 24.86 \\
\hline ACET & 12 & 10.91 & 19 & 11.24 & 19 & 9.50 & 9 & 12.50 & 59 & 10.71 \\
\hline ALCET & 7 & 6.36 & 16 & 9.47 & 9 & 4.50 & 5 & 6.94 & 37 & 6.72 \\
\hline CCET & 14 & 12.73 & 15 & 8.88 & 36 & 18.00 & 9 & 12.50 & 74 & 13.43 \\
\hline PMCET & 8 & 7.27 & 10 & 5.92 & 12 & 6.00 & 6 & 8.33 & 36 & 6.53 \\
\hline MVIT & 24 & 21.82 & 22 & 13.02 & 24 & 12.00 & 15 & 20.83 & 85 & 15.43 \\
\hline RAAKCET & 3 & 2.73 & 5 & 2.96 & 2 & 1.00 & 1 & 1.39 & 11 & 2.00 \\
\hline RGCET & 12 & 10.91 & 29 & 17.16 & 38 & 19.00 & 11 & 15.28 & 90 & 16.33 \\
\hline SGCET & 4 & 3.64 & 5 & 2.96 & 11 & 5.50 & 2 & 2.78 & 22 & 3.99 \\
\hline Total & 110 & 100 & 169 & 100 & 200 & 100 & 72 & 100 & 551 & 100 \\
\hline$\%$ & 19.96 & & 30.67 & & 36.30 & & 13.07 & & 100 & \\
\hline
\end{tabular}


Table 7 Opinion of the respondents on the Devices used for SM platforms

\begin{tabular}{|l|c|c|c|c|c|c|c|c|c|c|}
\hline \multicolumn{1}{|c|}{ Institution } & PC & $\mathbf{\%}$ & Laptop & $\mathbf{\%}$ & Mobile & $\mathbf{\%}$ & Tablet & \% & Total & \% \\
\hline PEC & 12 & 18.75 & 43 & 24.57 & 65 & 26.10 & 17 & 26.98 & 137 & 24.86 \\
\hline ACET & 8 & 12.50 & 19 & 10.86 & 23 & 9.24 & 9 & 14.29 & 59 & 10.71 \\
\hline ALCET & 5 & 7.81 & 14 & 8.00 & 13 & 5.22 & 5 & 7.94 & 37 & 6.72 \\
\hline CCET & 9 & 14.06 & 19 & 10.86 & 37 & 14.86 & 9 & 14.29 & 74 & 13.43 \\
\hline PMCET & 6 & 9.38 & 16 & 9.14 & 11 & 4.42 & 3 & 4.76 & 36 & 6.53 \\
\hline MVIT & 9 & 14.06 & 25 & 14.29 & 45 & 18.07 & 6 & 9.52 & 85 & 15.43 \\
\hline RAAKCET & 2 & 3.13 & 6 & 3.43 & 2 & 0.80 & 1 & 1.59 & 11 & 2.00 \\
\hline RGCET & 9 & 14.06 & 26 & 14.86 & 44 & 17.67 & 11 & 17.46 & 90 & 16.33 \\
\hline SGCET & 4 & 6.25 & 7 & 4.00 & 9 & 3.61 & 2 & 3.17 & 22 & 3.99 \\
\hline Total & 64 & 100 & 175 & 100 & 249 & 100 & 63 & 100 & 551 & 100 \\
\hline$\%$ & 11.62 & & 31.76 & & 45.19 & & 11.43 & & 100 & \\
\hline
\end{tabular}

With regard to the use of Tablets for accessing to SM platforms, out of 63 respondents, 17 (26.98\%) were from PEC followed by RGCET (17.46\%), ACET (14.29\%), CCET (14.29\%), MVIT (9.52\%), ALCET (7.94\%), PMCET (4.76\%), SGCET (3.17\%), and RAAKCET $(1.59 \%)$.

\section{Opinion of the respondents on the purpose of using SM platforms}

An attempt was made to analyse various purposes of using SM platforms to identify the significant difference among the respondents. As indicated in Table8, out of 73 faculty respondents, 90.41 percent of them made use of SM platforms for Academic purpose followed by Promoting own research/publication (89.04\%), Sharing experiences $(80.82 \%)$, Finding information about conference/seminars, etc. (76.71\%), Online discussion $(65.75 \%)$, Meeting new people (57.53\%), Sharing photos and videos $(57.53 \%)$, Interacting with friends $\&$ families (53.42\%), Chatting (28.77\%), Entertainment (26.03\%), Games (15.07\%), Job searching (12.33\%), and Lurking - watching posts passively $(8.22 \%)$.

On the other hand, out 478 student respondents, 98.12 percent of them made use of SM platforms for Sharing photos and videos followed by Job searching (97.91\%), Entertainment (97.7\%), Meeting new people (96.65\%), Online discussion (96.44\%), Interacting with friends \& families (95.82\%), Chatting (94.56\%), Games (94.35\%), Sharing experiences $(62.34 \%)$, Lurking (50.42\%), Academic (34.31\%), Finding information about conference/seminars, etc. (30.54\%), and Promoting own research/publication (25.31\%).

Table 8 Opinion of the respondents on the Purpose of using SM platforms

\begin{tabular}{|c|l|c|c|c|c|}
\hline S. No. & \multicolumn{1}{|c|}{ Purpose } & $\begin{array}{c}\text { Faculty } \\
(\mathbf{N = 7 3 )}\end{array}$ & $\mathbf{\%}$ & $\begin{array}{c}\text { Students } \\
(\mathbf{N = 4 7 8 )}\end{array}$ & \% \\
\hline 1. & Chatting & 21 & 28.77 & 452 & 94.56 \\
\hline 2. & Entertainment & 19 & 26.03 & 467 & 97.70 \\
\hline 3. & Academic & 66 & 90.41 & 164 & 34.31 \\
\hline 4. & Sharing experiences & 59 & 80.82 & 298 & 62.34 \\
\hline 5. & Online discussion & 48 & 65.75 & 461 & 96.44 \\
\hline 6. & Games & 11 & 15.07 & 451 & 94.35 \\
\hline 7. & Meeting new people & 42 & 57.53 & 462 & 96.65 \\
\hline 8. & Job searching & 9 & 12.33 & 468 & 97.91 \\
\hline 9. & Sharing photos and videos & 42 & 57.53 & 469 & 98.12 \\
\hline 10. & Lurking (watching posts passively) & 6 & 8.22 & 241 & 50.42 \\
\hline 11. & Interacting with friends \& families & 39 & 53.42 & 458 & 95.82 \\
\hline 12. & Promoting own research/publication & 65 & 89.04 & 121 & 25.31 \\
\hline 13. & Finding information about & & & & \\
& conference/seminars, etc. & 56 & 76.71 & 146 & 30.54 \\
\hline
\end{tabular}




\section{Opinion of the respondents on the statement "Using social media tools makes it easy to organize and access various social activities"}

An opinion was sought from the respondents based on the statement whether "Using social media tools makes it easy to organize and access various social activities". Table 9 indicates that out of 551 respondents, $71(12.89 \%)$ of them strongly agreed with the statement while $125(22.69 \%)$ respondents somewhat agreed; 197 (35.75\%) respondents neither agreed nor disagreed; $100(18.15 \%)$ respondents somewhat disagreed; and $60(10.89 \%)$ respondents strongly disagreed.

Institution wise analysis of the opinion on the above statement revealed that out of 71 respondents who strongly agreed, $18(25.35 \%)$ are from PEC that ranks first followed by CCET (16.9\%), RGCET (16.9\%), ACET (12.68\%), MVIT (12.68\%), PMCET (7.04\%), ALCET (5.63\%), RAAKCET (1.41\%), and SGCET (1.41\%). Out of $125(22.69 \%)$ respondents who somewhat agreed, $28(22.4 \%)$ are from PEC that ranks first in order followed by RGCET (19.2\%), MVIT (16.8\%), CCET (12.8\%), ACET (11.2\%), ALCET (7.2\%), PMCET (5.6\%), RAAKCET (2.4\%), and SGCET (2.4\%). Out of $197 \quad(35.75 \%)$ respondents who neither agreed nor disagreed, 48 (24.37\%) are from PEC that ranks first in order followed by MVIT (18.27\%), RGCET (16.75\%), CCET (13.71\%), ACET (11.68\%), PMCET (5.58\%), SGCET (4.57\%), ALCET (3.55\%), and RAAKCET (1.52\%).

On the other hand, out of $100(18.15 \%)$ respondents who somewhat disagreed, $31(31 \%)$ are from PEC that ranks first in order followed by MVIT (12\%), ALCET (11\%), RGCET (11\%), CCET (10\%), ACET (9\%), PMCET (8\%), SGCET (5\%), and RAAKCET (3\%). Out of $60(10.89 \%)$ respondents who strongly disagreed, $12(20 \%)$ are from PEC that ranks first in order followed by RGCET (16.67\%), CCET (15\%), MVIT (11.67\%), ACET (10\%), ALCET (10\%), PMCET (8.33\%), SGCET (6.67\%), and RAAKCET (1.67\%).

Table 9 Opinion of the respondents on "Using social media tools makes it easy to organize and access various social activities"

\begin{tabular}{|c|c|c|c|c|c|c|c|c|c|c|c|c|}
\hline 营 & 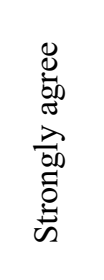 & $a^{\circ}$ & 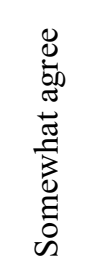 & $\alpha^{\circ}$ & 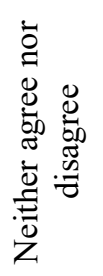 & $a^{\circ}$ & 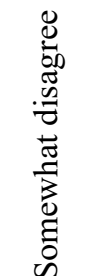 & $a^{\circ}$ & 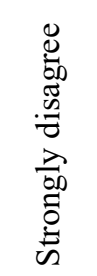 & $a^{\circ}$ & $\stackrel{\bar{\pi}}{0}$ & $a^{\circ}$ \\
\hline PEC & 18 & 25.35 & 28 & 22.40 & 48 & 24.37 & 31 & 31.00 & 12 & 20.00 & 137 & 24.86 \\
\hline ACET & 9 & 12.68 & 14 & 11.20 & 23 & 11.68 & 9 & 9.00 & 6 & 10.00 & 59 & 10.71 \\
\hline ALCET & 4 & 5.63 & 9 & 7.20 & 7 & 3.55 & 11 & 11.00 & 6 & 10.00 & 37 & 6.72 \\
\hline CCET & 12 & 16.90 & 16 & 12.80 & 27 & 13.71 & 10 & 10.00 & 9 & 15.00 & 74 & 13.43 \\
\hline PMCET & 5 & 7.04 & 7 & 5.60 & 11 & 5.58 & 8 & 8.00 & 5 & 8.33 & 36 & 6.53 \\
\hline MVIT & 9 & 12.68 & 21 & 16.80 & 36 & 18.27 & 12 & 12.00 & 7 & 11.67 & 85 & 15.43 \\
\hline RAAKCET & 1 & 1.41 & 3 & 2.40 & 3 & 1.52 & 3 & 3.00 & 1 & 1.67 & 11 & 2.00 \\
\hline RGCET & 12 & 16.90 & 24 & 19.20 & 33 & 16.75 & 11 & 11.00 & 10 & 16.67 & 90 & 16.33 \\
\hline SGCET & 1 & 1.41 & 3 & 2.40 & 9 & 4.57 & 5 & 5.00 & 4 & 6.67 & 22 & 3.99 \\
\hline Total & 71 & 100 & 125 & 100 & 197 & 100 & 100 & 100 & 60 & 100 & 551 & 100 \\
\hline$\%$ & 12.89 & & 22.69 & & 35.75 & & 18.15 & & 10.89 & & 100 & \\
\hline
\end{tabular}




\section{Opinion of the respondents on the statement "Using social media tools provide a significant advantage in teaching and learning process"}

Table 10 indicates based on the statement "Using social media tools provide a significant advantage in teaching and learning process" that out of 551 respondents, $47(8.53 \%)$ of them strongly agreed with the statement while 138 (25.05\%) respondents somewhat agreed; 222 $(40.29 \%)$ respondents neither agreed nor disagreed; 80 (14.52\%) respondents somewhat disagreed; and $64(11.62 \%)$ respondents strongly disagreed.

Institution wise analysis of the opinion on the above statement revealed that out of 47 respondents who strongly agreed, $11(23.4 \%)$ are from RGCET that ranks first followed by PEC (19.15\%), MVIT (19.15\%), ACET (10.64\%), CCET (10.64\%), RAAKCET (6.38\%), ALCET (4.26\%), PMCET (4.26\%), and SGCET (2.13\%). Out of 138 (25.05\%) respondents who somewhat agreed, $26(18.84 \%)$ are from RGCET that ranks first in order followed by CCET (16.67\%), PEC (15.22\%), MVIT (15.22\%), ACET (13.77\%), PMCET (7.97\%), ALCET (7.25\%), SGCET (2.9\%), and RAAKCET (2.17\%). Out of 222 (40.29\%) respondents who neither agreed nor disagreed, $61(27.48 \%)$ are from PEC that ranks first in order followed by MVIT (17.57\%), RGCET (16.22\%), CCET (13.06\%), ACET (9.91\%), ALCET (5.86\%), PMCET (5.41\%), SGCET (3.6\%), and RAAKCET (0.9\%).

On the other hand, out of $80(14.52 \%)$ respondents who somewhat disagreed, RGCET (13.75\%), CCET (12.5\%), MVIT (12.5\%), ACET (7.5\%), ALCET (7.5\%), PMCET (6.25\%), SGCET $(6.25 \%)$, and RAAKCET $(1.25 \%)$. Out of $64(11.62 \%)$ respondents who strongly disagreed, $20(31.25 \%)$ are from PEC that ranks first in order followed by ACET $(10.94 \%)$, CCET (10.94\%), ALCET (9.38\%), PMCET (9.38\%), MVIT (9.38\%), RGCET (9.38\%), SGCET (6.25\%), and RAAKCET (3.13\%).

Table 10 Opinion of the respondents on "Using social media tools provide a significant advantage in teaching and learning process"

\begin{tabular}{|c|c|c|c|c|c|c|c|c|c|c|c|c|}
\hline Institution & 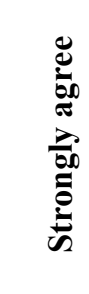 & $\theta^{\circ}$ & 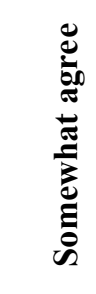 & $a^{\circ}$ & 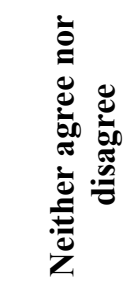 & $a^{\circ}$ & 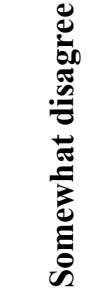 & $0^{\circ}$ & 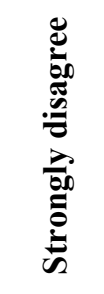 & $0^{\circ}$ & हूँ & $\%$ \\
\hline PEC & 9 & 19.15 & 21 & 15.22 & 61 & 27.48 & 26 & 32.50 & 20 & 31.25 & 137 & 24.86 \\
\hline ACET & 5 & 10.64 & 19 & 13.77 & 22 & 9.91 & 6 & 7.50 & 7 & 10.94 & 59 & 10.71 \\
\hline ALCET & 2 & 4.26 & 10 & 7.25 & 13 & 5.86 & 6 & 7.50 & 6 & 9.38 & 37 & 6.72 \\
\hline CCET & 5 & 10.64 & 23 & 16.67 & 29 & 13.06 & 10 & 12.50 & 7 & 10.94 & 74 & 13.43 \\
\hline PMCET & 2 & 4.26 & 11 & 7.97 & 12 & 5.41 & 5 & 6.25 & 6 & 9.38 & 36 & 6.53 \\
\hline MVIT & 9 & 19.15 & 21 & 15.22 & 39 & 17.57 & 10 & 12.50 & 6 & 9.38 & 85 & 15.43 \\
\hline RAAKCET & 3 & 6.38 & 3 & 2.17 & 2 & 0.90 & 1 & 1.25 & 2 & 3.13 & 11 & 2.00 \\
\hline RGCET & 11 & 23.40 & 26 & 18.84 & 36 & 16.22 & 11 & 13.75 & 6 & 9.38 & 90 & 16.33 \\
\hline SGCET & 1 & 2.13 & 4 & 2.90 & 8 & 3.60 & 5 & 6.25 & 4 & 6.25 & 22 & 3.99 \\
\hline Total & 47 & 100 & 138 & 100 & 222 & 100 & 80 & 100 & 64 & 100 & 551 & 100 \\
\hline$\%$ & 8.53 & & 25.05 & & 40.29 & & 14.52 & & 11.62 & & 100 & \\
\hline
\end{tabular}

\section{Opinion of the respondents on the positive influence of using SM tools and platforms}

Table 11 provides the opinions of the respondents on the positive influence of using SM tools and platforms. The result indicates that out of 73 faculties, 94.52 percent of them opined that use of SM tools and platforms positively influences the Dissemination of research results followed by Collaborative \& peer learning (93.15\%), Keep updated in the field $(82.19 \%)$, 
Better relations with peer experts $(80.82 \%)$, Involvement in social \& cultural activities (79.45\%), Collaborative working opportunity (78.08\%), Help save time \& money $(67.12 \%)$, Collation of resources (67.12\%), and Developing e-portfolio for future employment $(31.51 \%)$.

On the other hand, out of 478 students, 93.72 percent of them opined that use of SM tools and platforms positively influences the Developing e-portfolio for future employment followed by Keep updated in the field (91.63\%), Involvement in social \& cultural activities (91.21\%), Help save time \& money (76.15\%), Collaborative \& peer learning $(72.38 \%)$, Collation of resources $(65.27 \%)$, Collaborative working opportunity $(51.26 \%)$, Better relations with peer experts (49.16\%), and Dissemination of research results $(44.14 \%)$.

\section{Opinion of the respondents on the Negative influence of using SM tools and platforms}

Table 12 provides the opinions of the respondents on the negative influence of using SM tools and platforms. The result indicates that out of 73 faculties, 84.93 percent of them opined that use of SM tools and platforms negatively influences the Neglecting social activities followed by Unable to concentrate on family/social life (83.56\%), Affecting academic performance $(80.82 \%)$, Lose effective learning time $(73.97 \%)$, Stay up late at night and sleep disorder (64.38\%), and Addiction to social media (49.32\%).

Table 12 Opinion of the respondents on the positive influence of using SM tools and platforms

\begin{tabular}{|c|c|c|c|c|c|}
\hline S. No. & Influencing Factor & $\begin{array}{c}\text { Faculty } \\
(\mathrm{N}=73)\end{array}$ & $\%$ & $\begin{array}{l}\text { Students } \\
(\mathrm{N}=478)\end{array}$ & $\%$ \\
\hline 1. & Better relations with peer experts & 59 & 80.82 & 235 & 49.16 \\
\hline 2. & Collaborative \& peer learning & 68 & 93.15 & 346 & 72.38 \\
\hline 3. & Developing e-portfolio for future employment & 23 & 31.51 & 448 & 93.72 \\
\hline 4. & Dissemination of research results & 69 & 94.52 & 211 & 44.14 \\
\hline 5. & Help save time \& money & 49 & 67.12 & 364 & 76.15 \\
\hline 6. & Involvement in social \& cultural activities & 58 & 79.45 & 436 & 91.21 \\
\hline 7. & Collation of resources & 49 & 67.12 & 312 & 65.27 \\
\hline 8. & Collaborative working opportunity & 57 & 78.08 & 245 & 51.26 \\
\hline 9. & Keep updated in the field & 60 & 82.19 & 438 & 91.63 \\
\hline
\end{tabular}

On the other hand, out of 478 students, 92.68 percent of them opined that use of SM tools and platforms negatively influences such as Stay up late at night and sleep disorder followed by Lose effective learning time $(90.38 \%)$, Unable to concentrate on family/social life (88.49\%), Addiction to social media (88.08\%), Neglecting social activities $(75.1 \%)$, and Affecting academic performance (67.15\%). (Table 13)

Table 13 Opinion of the respondents on the Negative influence of using SM tools and platforms

\begin{tabular}{|c|c|c|c|c|c|}
\hline S. No. & Influencing Factor & $\begin{array}{r}\text { Faculty } \\
(\mathrm{N}=73)\end{array}$ & $\%$ & $\begin{array}{c}\text { Students } \\
(\mathrm{N}=478)\end{array}$ & $\%$ \\
\hline 1. & Addiction to social media & 36 & 49.32 & 421 & 88.08 \\
\hline 2. & Stay up late at night and sleep disorder & 47 & 64.38 & 443 & 92.68 \\
\hline 3. & Lose effective learning time & 54 & 73.97 & 432 & 90.38 \\
\hline 4. & Affecting academic performance & 59 & 80.82 & 321 & 67.15 \\
\hline 5. & Neglecting social activities & 62 & 84.93 & 359 & 75.10 \\
\hline 6. & Unable to concentrate on family/social life & 61 & 83.56 & 423 & 88.49 \\
\hline
\end{tabular}

\section{FINDINGS AND CONCLUSION}

The outcomes of the study on the use of social media platforms by the faculties and students of engineering colleges in Puducherry led to the following significant findings such as 91.05 percent of the total respondents made use of Skype; only 12.34 percent of the respondents 
checked the analytics of social media activities daily; 7.8 of the respondents used SM platforms very frequently, and 22.87 percent frequently. 4.54 percent of the respondents used SM platforms for Less than a Month while 18.33 percent of them spent less than one hour a week on SM platforms; 19.96 percent of the respondents opined that they used Library for accessing to SM platforms while 169 (30.67\%) used Hostels, 200 (36.3\%) used Institute Campus; and 72 (13.07\%) used Cyber Café. Interestingly, it was found that 90.41 percent of the faculty respondents made use of SM platforms for Academic purposes while 98.12 percent of the students made use of SM platforms for Sharing photos and videos. It was also opined that the use of social media platforms has positively influenced the respondents. However, a good number of respondents have also revealed that there was negative influence on the use of social media platforms.

\section{REFERENCES}

[1] Aleryani, A.Y., Mofleh, H., \& Alariki, S. (2017). The Usage of Academic Social Network Sites by Researchers in Developing Countries: Opportunities and Challenges, Saba Journal of Information Technology and Networking (SJITN), 5(2), 49-59.

[2] Alexa (2008). Facebook overtakes MySpace. Retrieved from http://blog.alexa.com/2008/05/Alexa.

[3] Ali, M.Y., \& Richardson, Joanna. (2017) Usage of academic social networking sites by Karachi social science faculty: Implications for academic libraries, International Federation of Library Associations and Institutions, XX (X), 1-12.

[4] Asmi, N.A., \& Margam, Madhusudhan. (2018) "Academic social networking sites for researchers in Central Universities of Delhi: A study of ResearchGate and Academia", Global Knowledge, Memory and Communication, 67 (1), pp.91-108.

[5] Governatoria, G., \& Iannella, R. (2011). A modelling and reasoning framework for social networks policies. Enterprise Information Systems, 5(1), 145-167. Retrieved from https://doi.org/10.1080/175 17575.2010.513014.

[6] Haque, A., Sarwar, A, \& Yasmin, F. (2013). Malaysian Users' Perception towards Facebook as a Social Networking Site. International Journal of Academic Research in Business and Social Sciences, 3(1), 119-130. Retrieved from http://www.hrmars.com/admin/pics/1415.pdf.

[7] Jeng, W., Des Autels, S., He, DQ., \& Li, L. (2017) Information Exchange on an Academic Social Networking Site: A Multidiscipline Comparison on ResearchGate Q\&A, Journal of the Association for Information Science and Technology, 68(3), 638-652.

[8] Kenchakkanavar, A.Y., Hadagali, G.S., \& Ranadev, S. (2017). Use of Academic Social Networking Sites by the Research Scholars in the Universities of Dharwad city: A study. Journal of Advances in Library and Information Science, 6(3), 274-278.

[9] Kroski, E. (2007). The social tools of Web 2.0: Opportunities for academic libraries. Choice, 44(12), 2011-21.

[10] Manca, Stefania \& Ranieri, Maria (2017) Networked scholarship and motivations for social media use in scholarly communication, International Review of Research in Open and Distributed Learning 18(2), 123-138. 
[11] Meishar-Tal, H., \& Pieterse, E. (2017) Why Do Academics Use Academic Social Networking Sites?,International Review of Research In Open And Distributed Learning,18(1), 1-22.

[12] Mering, M. (2017). Correctly Linking Researchers to Their Journal Articles: An Overview of Unique Author Identifiers. Serials Review, 43(3-4), 265-267.

[13] Minocha, S. (2009). Role of social software tools in education: a literature review. Education Plus Training, 51(5/6), 353-369.

[14] Murray, K. E., \& Waller, R. (2007). Social networking goes abroad. International Educator, 16(3), 56.

[15] Russo, A., Watkins, J., Kelly, L., \& Chan, S. (2008). Participatory communication with social media. Curator: The Museum Journal, 51(1), 21-31.

[16] Steinfield, C., Ellison, N. B., \& Lampe, C. (2008). Social capital, self-esteem, and use of online social network sites: A longitudinal analysis. Journal of Applied Developmental Psychology, 29(6), 434-445.

[17] Suraweera, N. S., Razali, N., Chouhan, L. B., Tamang, N., Hubilla, A. M. K. U., Ratnayake, A. M., \& Mahesar, S. N. (2010, August). Value of social networking in libraries and information organizations in Asia and Oceania. In Gothenburg, Sweden: World Library and Information Congress: 76th IFLA General Conference And Assembly. Retrieved from http://conference.ifla. org/past/2010/145-suraweera-en.pdf.

[18] Yan, W., \& Zhang, Y. (2018) Research universities on the ResearchGate social networking site: An examination of institutional differences, research activity level, and social networks formed, Journal of Informetrics, 12,385-400.

[19] Zientek, L.R., Werner, J.M., Campuzano, M.V., \& Nimon, K. (2018). The Use of Google Scholar for Research and Research Dissemination, New Horizons in Adult Education and Human Resource Development, 30(1), 39-46. 